\title{
East African discourses on khat and sex
}

\author{
Susan Beckerleg* \\ School of Health and Social Studies, University of Warwick, Coventry, CV4 7AL, UK
}

\section{A R T I C L E I N F O}

\section{Article history:}

Received 5 October 2009

Received in revised form 14 June 2010

Accepted 28 August 2010

Available online 9 September 2010

\section{Key words:}

Khat

East Africa

Sex

Violence

Fertility

Morality

\begin{abstract}
A B S T R A C T
Aim of the study: The study aims to review and analyse the varied East African discourses on the effects of khat use on libido, fertility, transmission of HIV, prostitution and rape.

Materials and methods: The data were gathered between 2004 and 2009 in Kenya and Uganda. Between 2004 and 2005 across Kenya and Uganda a broad survey approach was adopted, involving identification of and travel to production areas, interviews with producers and consumers in rural and urban settings. In addition, a survey of 300 Ugandan consumers was carried out in late 2004. Between 2007 and 2009, an in-depth study of khat production, trade and consumption was conducted in Uganda. This study also employed a mixture of methods, including key informant interviews participant-observation and a questionnaire survey administered to 210 khat consumers.

Results: Khat is associated, by consumers and its detractors alike, with changes in libido and sexual performance. Although there is no evidence to support their claims, detractors of khat use argue that khat causes sexual violence, causes women to enter sex work, and that chewing causes the spread of sexually transmitted diseases, including the HIV virus.

Conclusions: In East Africa the discourse on khat and sex has led to consumption of the substances being associated by many people with uncontrolled sexual behaviour. There is no evidence that khat use fuels promiscuity, commercial sex, sexually transmitted diseases or rape. The current discourse on khat and sex touches on all these topics. Local religious and political leaders invoke khat use as a cause of what they argue is a breakdown of morals and social order. In Kenya and Uganda it is women khat consumers who are seen as sexually uncontrolled. In Uganda, the argument is extended even to men: with male khat chewers labelled as prone to commit rape.
\end{abstract}

(C) 2010 Elsevier Ireland Ltd. All rights reserved.

\section{Introduction}

This article outlines the diverse ways that drug experts, concerned officials, lay people and khat users in Kenya and Uganda link khat and sex. The emphasis of the article is on the discussions and arguments (discourse) about the effects of khat, and is not a review of the empirical evidence of khat and sexuality. The discourse on khat and sex is one aspect of the controversies surrounding khat use (Anderson et al., 2007) that have continued through the twentieth century. Hence, a League of Nations advisory committee on khat report, back in 1936, set the trend for prevarication, when stating that there was 'no proof one way or the other of its specific negative effects' (Gebissa, 2004, p. 18). WHO reviews in the 1950s, 1970s and 1980s also found that there was insufficient medical evidence of harm. In 2005 the Advisory Council on the Misuse of Drugs undertook a major review of khat in the UK, and recommended that the substance remain legal, but

\footnotetext{
* Tel.: +44 247652 3164; fax: +4418 03868258.

E-mail addresses: Susan.beckerleg@warwick.ac.uk, S.Beckerleg@warwick.ac.uk.
}

doubts persist amongst policy makers, as there is a lack of good quality studies on the effects of khat use (Anderson and Carrier, 2006; Klein and Beckerleg, 2007; Klein et al., 2009). As khat continues along a pathway to international prohibition, arguments about several types of harm by khat use are deployed by policy makers: chewing causes: ill health (ACMD, 2005; Anderson et al., 2007); psychiatric disorders (Dhadphale and Omolo, 1988; Odenwald, 2007; Warfa et al., 2007), and socio-economic hardship for the families of mostly male consumers (Borelli and Perali, 2004; Kennedy, 1987).

A gendered moral battle is raging over khat both in East Africa and the diaspora (Klein and Beckerleg, 2007). Khat is associated by many observers, both academic and lay, with the breakdown of family life, prostitution and a host of social evils (Beckerleg, 2008). Male consumption is usually highlighted as damaging and irresponsible. Thus, a study of consumption in Djibouti found that qat (khat) consumption, mostly by men, is associated with higher inequality in distribution of resources within the family (Borelli and Perali, 2004:186). Somali women, particularly those in the diaspora deploy similar arguments in their campaign against khat (Klein and Beckerleg, 2007). 
Other, less widely reported, controversies concerning the substance are about the effects of khat use on sexual behaviour. In East Africa consumers of khat, health and development workers and policy makers all have strong, and often contradictory, views concerning the effects of khat in relation to: fertility, libido and performance, sexual health, female sexuality and self control, and sexual violence. In this paper the arguments about khat and sex are set out and discussed within the East African context.

This paper explores four main aspects of the East African discourse on khat and sex: khat effects of libido; performance and fertility; female respectability, sex work and STD; Rape and violence; breakdown of community and morality. The primary purpose of this paper is not to evaluate the evidence with regard to the effects of khat on libido and fertility, but to show that the ways that pronouncements on the substance are used as part of debates on social order and the control of women in parts of Kenya and Uganda.

\section{Methods}

The research findings presented in this paper were gathered between 2004 and 2009 in Kenya and Uganda, in two separate studies. The data were collected through semi-structured interviews and questionnaire surveys. The principal research method of participant-observation was also used during khat chewing sessions which offered a good opportunity for data collection on the views of consumers during khat-enhanced conversation. These research projects were not specific studies of khat and sex. Although the findings related to khat and sexuality are fragmentary, they provide fresh insights into the discourse on khat and sex, a debate which may have a strong bearing on policy and moves to prohibit or regulate the substance in East Africa.

Between 2004 and 2005 across Kenya and Uganda a broad survey approach was adopted, involving identification of and travel to production areas, interviews with producers and consumers in rural and urban settings. Khat consumers and traders were able to direct the research team to the production areas, which were then visited and khat farmers or harvesters were interviewed about the history of and basic principles of local production and marketing (Anderson et al., 2007). Data collection was geared towards breadth, rather than a detailed study of one region. Indeed the aim was to assess the extent of khat production and consumption across Kenya and Uganda. In Uganda the survey was the first study of Ugandan khat production and distribution.

In addition, a questionnaire survey of 300 Ugandan consumers was carried out in late 2004. Two interviewers were trained to administer a brief questionnaire to khat users as they chewed in meeting places, homes and businesses around Kampala and other major towns (primarily Kasese and Fort Portal) in the extreme west of Uganda. Respondents were asked a number of questions about what they thought about the effects of khat chewing. Some of survey participants also responded to the invitation to make any other comment concerning khat consumption. Most of those who took this opportunity mentioned that loss the appetite and sleep as major effects of khat chewing, but many also commented upon the effects of khat on sexuality. The survey results were analysed using the SPSS package.

Between 2007 and 2009, an in-depth study of khat production, trade and consumption was conducted in Uganda. Data were collected as part of an ESRC study on 'Khat and Social Identity in Uganda'. In December 2007, an initial survey of all major khatproducing areas was completed and from January 2008 fieldwork concentrated in Kaborole District in Western Uganda, in the capital,
Kamplala and in the nearby khat plantations serving this market. Data were collected through:

(1) Observation and interviews of the khat production, harvesting and wholesale market centres on the rural production areas.

(2) Participant observation of khat sales and consumption in retail outlets, chewing clubs and people's homes.

(3) Key informant interviews with key informant interviews with government officials, health workers, the police, and NGO workers.

Between February 2008 and March 2009, 210 khat consumers were interviewed using a questionnaire concerning their khat consumption and post-consumption behaviour. As in the 2004 questionnaire survey, a convenience sample that recruited consumers chewing in venues, such as clubs, bars and alleyways and at home was used. This research design ensured that all respondents were active consumers of khat, and that all questions on the short questionnaire applied to them. The main purpose of the questionnaire was to collect data on reported behaviour in relation to combining khat consumption with other drug use, particularly alcohol. Just over half (113) the interviews were conducted in and around Kampala, while 73 interviews took place in and around the western towns of Fort Portal, Kasese and Mbarara. Other interviews were conducted in the towns of Bombo, Gulu and Lira, while four interviews were conducted in the trading centre of Namalu in Karamoja.

These methods produced diverse data sets providing a mass of information on khat production, marketing and its use in Kenya and Uganda. The data point to a wide range of reported views about khat and sex. In this paper I concentrate on the expressed views, or discourses, on khat in these two East African countries. The statements and writings of these diverse commentators on khat are analysed in terms of their significance to contemporary religious, social and political issues in the region. The data are supplemented by reference to studies about khat and sex in Ethiopia and by selected works on khat and sex. Some of the topics presented in the results section are fragmentary, because they do not include the views of all groups of commentators on khat.

\section{Results}

The results presented summarise the multiple discourses on khat in Kenya and Uganda amongst, civil servants and local leaders; journalists; khat users and traders. The academic literature that supports or contradicts the views of East African consumers and policy makers are also presented.

\subsection{Libido, performance and fertility}

'Sex and Mairungi' screamed the headline in the Ugandan newspaper Red Pepper, explaining in the sub-heading: 'with mairungi ${ }^{1}$ of only Sh $500^{2}$ you can romp for four hours non-stop'. In July 2008 , Red Pepper published under these headlines a discussion of khat and sexuality that was both sensationalist and purulent. The article drew on one of the most popular topics of conversation by consumers talking about khat. The article quoted, Nasser, an indigenous Ugandan khat trader:

'Nasser added that khat is largely gainful because khat leaves are believed to give men more stamina to shaft women without getting tired. He gave an example of Somali men who always

\footnotetext{
1 Mairungi is the local name for name in Uganda.

2 Uganda Shillings 500 is about US\$0.25.
} 
chew khat and are well known for being sex maniacs. He advised if we wanted to have the same sexual powers we should chew khat one or two hours before the sexual encounter for maximum results.' (Red Pepper, 2008, p. 8)

Somali Ugandan citizens and Somali refugees in Uganda are seen to be keen consumers of khat and I have heard Somalis being singled out as 'sex maniacs' by Ugandans discussing the effects of khat. However, the views of many Somalis on the effects of khat on sexual performance are different from the racist stereotyping heard in Uganda. Hence, Carrier, in a paper on Kenyan attitudes to khat, notes that Kenyan Somali women link khat with physical and metaphorical impotence:

'Some Somali women put the blame for marriage break-ups, male unemployment, and male impotence - both sexual and in a broader sense-on miraa. Indeed talk of a diminution of male sexual potency metaphorically hints at a wider male impotence to look after families. Women lament that some men prefer miraa to them.' (Carrier, 2008, p. 807)

According to data presented by Carrier, the dominant Kenyan discourse emanating from the media is that khat causes impotence. Carrier (2008), p. 810 cites a psychiatrist on a television chat show in 2000 stating that 'impotence and malnutrition were the consequences of long term miraa use'. Furthermore, the website of the Kenyan National Agency for the Campaign against Drug Abuse (NACADA) warns 'chew miraa, be impotent' (Carrier, 2008, p. 811).

Across East Africa, khat is associated by people from different ethnic backgrounds with changes in libido and sexual performance. Hence, Ugandan khat users who were surveyed in 2004 were asked if they wanted to add any comments to questionnaire forms (Beckerleg, 2006). Many chose to comment on khat and sexual performance. Comments from male respondents in the 2004 survey included:

"It gives a man strength, especially a married man."

"It makes me sexually weak. Sleepless nights and it disorganises me."

"It makes some people impotent. You don't need a woman. It also causes loss of appetite and loss of sleep."

One woman respondent commented:

"It is an appetiser sexually. After chewing you will need a man."

Academics are as divided as consumers over the effects of khat on libido and fertility.

Hakim (2002), reporting on one of the few studies that used population-based human subjects, concludes that khat exacerbates impotence. Hakim (2002), p. 22 studied 214 male patients in Ethiopia with 'a history of infertility and substance use of khat alone or in combination with tobacco smoking, coffee drinking and alcohol intake of over one year'. According to Hakim (2002), p. 22 khat causes: 'depressed overall sexual potency'. Reduced sexual potency was further associated with 'insignificant' decreased volume and sperm count in Ethiopian khat users compared with non-khat users.

Infertility, however, is not a common cause of concern amongst male Kenyan and Ugandan khat consumers, according to my informants. Women in East Africa however, often complained to me during fieldwork about male khat chewers' lack of interest in sex and their inability to perform sexually. This impotence is considered a cause of male infertility by the wives and partners of heavy consumers.

Hakim also reports a 'possible association' with abnormal semen in Ethiopian khat users and notes that 'leaking semen' is 'common' but is not understood by medical scientists. In Ethiopia it is associated with 'white' khat (Hakim, 2002). The concern with 'leaking semen' reported by Hakim in Ethiopia is shared by Kenyan and Ugandan consumers, and linked by them to particular, usu- ally cheap, varieties of khat. Kenyan and Ugandan khat users have expressed concerns about 'leaking sperms' to me in informal discussions over the years, and were sometimes worried that the phenomenon might be adversely affecting their fertility. Hence, Hakim's findings concerning the effects of fertility do 'match' the non-scientific discourse. Most of the lay discourse on khat and sex that I have heard over the years centres on libido and sexual performance.

In a critical review of the literature on khat and reproductive function Mwenda et al. (2003), p. 318, found that 'khat chewing lowers libido in humans and may also lead to sexual impotence following long term use'. They conclude that 'the limited data reveal that chewing of khat has a negative impact on human reproductive health' although the 'precise mechanisms effecting reproductive physiology have not been elucidated' (Mwenda et al., 2003, p. 318).

A study by Mwenda et al. (2006), p. 379 looked at circulating hormones in baboons administered with khat. The study found that: 'The results showed that khat administration causes a significant increase in the mean levels of testosterone while prolactin and cortisol levels were reduced.' (Mwenda et al., 2006, p. 379).

Another study of the effects of khat on testosterone, this time in mice (Nyongesa et al., 2007), produced mixed results in terms of the production of testosterone in mouse cells incubated with concentrations of khat. No definitive finding was achieved by this study, but the authors present an appropriately cautious conclusion:

'We postulate that khat extract at high concentrations may cause reproductive function impairment in the user but at low concentrations, may enhance testosterone production with accompanying effects on reproductive functions in male mice' (Nyongesa et al., 2007: 401)

However, as Gebissa notes in this volume, findings leading to the conclusion that khat has a negative effect on sexual potency and sperm production have been contradicted by some other recent studies. Hence, Al-Mamary et al. (2002) found that khat stimulates sperm production, while Adeoya-Osiguwa and Fraser (2004) found that cathine contained in khat may enhance fertility. This finding attracted considerable media interest (Ainsworth, 2004; Ryan, 2004). Although the suggestion that khat may promote male fertility attracted media and academic attention in 2004, the ongoing controversy as to whether khat has a positive or negative effect on sexuality and fertility continues.

Laboratory-based studies have done little to settle the controversy about the effects of khat on sexual function and fertility. Khat consumers and their sexual partners will continue to offer contradictory opinion on the subject, even if scientific studies do, at some future point, provide non-contradictory evidence of the effects of khat on human sexual function.

\subsection{Female respectability, sex work and sexually transmitted disease}

Men in East Africa often link women's khat consumption to sexual immorality. An information leaflet, published by the Nairobi office of the UNODC sets the tone for the debate on women's khat use:

'Concern has been expressed in a number of khat-consuming countries that, what was traditionally a male activity, is also attracting a growing number of women users. This trend is viewed with alarm, as it is associated with a loosening of moral mores and values.' (UNODC, undated)

Hence, it is female consumption that is associated with sexual immorality by the UNODC. As khat use gains popularity across Kenya, particularly amongst male youth, disapproval of 
khat consumption as a leisure pursuit is widespread amongst both government and the people (Beckerleg, 2008). Yet, Carrier reports that khat consumption has become a fashionable pastime amongst youth of all ethnic groups across Kenya. While most of these youth are male, some young women have also taken up khat (Carrier, 2005). These youthful chewers join Kenyan communities that have adopted khat consumption during the twentieth century. The Somali are foremost ethnic group amongst consumers, but khat use is also popular amongst the Swahili, the Turkana and the Borana.

In Eastleigh, Nairobi, which has a predominantly Somali population as well as numerous lodgings catering for Somali visitors, there are over 300 khat shops/kiosks operating between 12th Street and 14th Street. According to male Somali informants interviewed in 2004 for the Khat Nexus project, much khat chewing in the local area takes place in lodgings where men bring khat to consume with resident sex workers (Beckerleg and Sheekh, 2005).

In Uganda I found that khat was not used for either ritual or recreational purposes until Yemenis and Somalis started teaching local people to first grow and then chew khat in the 1930s (Beckerleg, 2009a). Emigration from Hadhramawt, in South Yemen and from north Yemen to East Africa has been occurring for centuries, and was particularly widespread in the first half of the twentieth century. Men typically came alone, set up small retail businesses and married local women (Beckerleg, 2009b). The Somali case is somewhat different. The first Somali settlers in Uganda were those who came from Somaliland during the period it was under British rule. As Somaliland is near the major khatproducing region of Harar in Ethiopia many Somalilanders started using khat long before Somalis living further south under Italian rule. Many of the early Somali settlers in Uganda had served in the Kings African Rifles and upon discharge were free to settle anywhere in British East Africa (Beckerleg, 2010) Ugandan Somalis have long faced discrimination from indigenous Ugandans who see them as socially aloof and alien, according to comments that I have frequently heard expressed. The longstanding Somali community in Uganda is seeking to be recognised as an indigenous Ugandan ethnic group. They also seek to distance themselves from khat consumption, claiming that chewing is popular amongst recent refugees from Somalia who recently arrived in the country (Beckerleg, 2010). Across Uganda, key informants report that in the past consumers were reputable businessmen, but now that khat chewing has become a youth fashion, it is no longer perceived as respectable. In addition, many Ugandan men share the views of their Kenyan neighbours concerning the negative effects of khat on women. Thus, young male khat farmers near the Ugandan capital, Kampala, said that women in their community are not allowed to chew, because if they do so they become uncontrollable wahuni (hooligans). They added that the Catholic Church, of which they were members, does not oppose khat chewing, but the Pentecostals and Seventh Day Adventists do (Beckerleg, 2008).

The majority of Ugandan chewers are men, but a large minority of women also chew. In the survey of 300 khat consumers carried out in 2004, we found that 71 respondents, about a quarter, were women. Respondents were interviewed as they chewed at home, their place of work or in public places such as street corners or bars, in Kampala and several towns and villages in Western Uganda. Of the 71 women consumers interviewed, 40 reported that they were married, 22 that they were single, while nine said they were divorced or widowed. Marriage does not, in itself, preclude sex work, but when asked about their occupation, the number claiming to be housewives (6) exceeded the number of self-reported sex workers (4). (The survey results show that 5 of the 300 respondents reported being a sex worker. However, one of these 5 sex workers was a man.) Other surveyed women worked as hawkers, retailers, cleaners or bar-staff (Beckerleg, 2008).
In the second questionnaire survey carried out between 2008 and 2009, 44 respondents were women. Again housewives outnumbered sex workers. Hence, there were 10 female respondents who reported that they were housewives, six said they were unemployed, and three gave their occupation as sex worker. Other female occupations ranged from khat seller, to journalist, to teacher (Beckerleg, 2010).

Condemnatory attitudes concerning the propriety of women using khat, combined with fears about a possible breakdown in women's sexual conduct, are widespread in East Africa. While Somali male attitudes to female khat consumption are condemnatory, another cultural group, the Swahili, have also started linking female consumption to prostitution. Many Swahili women chew, although mostly at home. Indeed, a khat wholesaler in the Swahili town of Malindi commented that most of his customers from other cultural groups were men, but amongst the Swahili, women outnumbered men as consumers. Khat consumption is not status enhancing for Swahili women and the practice lacks respectability (Anderson et al., 2007).

\subsection{Breakdown of community and morality}

Between 2001 and 2002 an anti-khat campaign was mounted in the Swahili town of Lamu. Much of the campaign focused on the breakdown of society in this Islamic town, which is also a major tourist destination (Beckerleg, 2006). In a series of letters (Beckerleg, 2006) sent to everybody from government to bus operators who carried khat, links were routinely made between khat and prostitution. For example, in June 2001 an appeal from the Imams of the Friday mosques was made to fellow Muslim, bus owners. Part of the letter read:

'Miraa [khat] as we are all aware has been a big menace and a cause of a number of problems in our Islamic community. Some of these problems are divorce, prostitution, begging and abandonment of families and etc...We would like you to please assist us by not allowing your vehicles to transport Miraa to Lamu. By this you will be to a large extent preventing divorces, prostitution (which leads to HIV/AIDS), begging and other malpractices and we are sure Allah's reward to you will be great.' (Quoted in Beckerleg, 2006: 223)

The following month, in a letter from 'Lamu District Community' to Kenya Airways, another approach was attempted:

'Sirs, Miraa imported and consumed by our youths and even elders is causing the district great damages, socially, economically and culturally. Socially, it is one of the major causes of rising crime rates, it is contributing high rises of disease e.g. STDs HIV/AIDS. Our district is now experiencing high rates of thefts and prostitution as well as other sexual crimes. Miraa is one of the great causes of broken marriages and divorces.' (Quoted in Beckerleg, 2006, 223)

In May 2002 the 'Anti-Drug Lobby' wrote the Minister of local Government:

'According to the records in the Kadhi's office and children office, Lamu District, miraa is one of the main contributions of divorces, family break-ups and separations. These effects further lead to social crimes such as prostitution, theft and unstable society morally.' (Quoted in Beckerleg, 2006: 225)

Many men interviewed in different parts of Kenya, from diverse ethnic backgrounds, share the fears of the Swahili leaders in Lamu, and argue that women should not use khat because, if they do, they will become prostitutes (malaya). Underlying these views appears to be widespread notion that women, as compared to men, lack self control in relation to their sexuality (Beckerleg, 2004). It appears 
that a small minority of women do, indeed, develop dependence on khat, to the extent that they are prepared to trade sex for the drug. It is this aspect of female consumption that the campaigners in Lamu focused upon as a major cause of concern about the social effects of khat (Beckerleg, 2008).

Apart from claiming that khat use was a cause of prostitution, the local leaders in Lamu, Kenya cited chewing as a cause of HIV and AIDS and other sexually transmitted infections. One of the letters sent during the anti-khat campaign in Lamu claimed that:

'Socially, it [khat] is one of the major causes of rising crime rates, it is contributing high rises of disease e.g. STDs HIV/AIDS.' (Quoted in Beckerleg, 2006: 223)

Kenyan health and NGO workers often make a link between khat and HIV transmission, despite having no evidence to support their stance. Yet, Somali dominated North Eastern Province, Kenya has the lowest rate of HIV infection in Kenya: just 0.8 per cent in 2007 , compared to 14.9 per cent in the worst affected Nyanza Province (Republic of Kenya, 2009: 9).

Although there is no evidence of any link between khat and sexually transmitted infections, Ethiopian detractors of khat make similar claims to those made by the Lamu campaigners. Hence, Gebissa cites comments by Woldemichael:

'Recently it has been observed that people with alcohol-use are more likely than the general population to contract HIV. It is therefore possible that the use of khat can promote this process through alcohol consumption...' (Gebissa, 2008, p. 789)

By contrast to other East African settings, no link between khat chewing and the transmission of HIV or other sexually transmitted infections is voiced by either consumers or leaders concerned with the rise of khat consumption (Ihunwo et al., 2004).

\subsection{Rape and violence}

Ugandan officials, such as the police and district officers, have, however, focused on khat as a cause of sexual violence. The discussion is particularly acute in Kabarole District in the Western region, one of the main growing areas. Police, local government officials and civil society groups have united in their negative views about the effects of khat because, as they see it (Klein et al., 2009):

- It is a dangerous drug used by criminals who want to stay awake at night to commit robberies.

- Khat consumers are prone to commit rape and defilement (a catch-all term covering sex with underage girls and actual paedophilia) because of the effects of chewing.

- Khat makes people violent.

- It is used by 'idlers' and causes people to be non-productive.

- Khat is mixed with cannabis and waragi (distilled liquor) with dangerous results in terms of behaviour-violence, crime and uncontrolled sex.

- Taxi and motorbike taxi drivers mix alcohol and khat and thus are very dangerous drivers.

The comments made to me by one senior policeman from southwest Uganda are typical of the views of officials in this part of the country:

'When people are high (on khat) they do 'funny things'-rape, petty crime. It makes people high like a drug. .... More than half the people we arrest are into khat and drugs.....These people are robbers and housebreakers and gang rapists.'

The linking of khat and sex to male violence appears to be unique to Uganda. Although the fears of many Ugandans that khat causes rape and 'defilement' are unfounded, such linkages between drugs and sexual violence are not uncommon, and the Uganda authorities are not the first national representatives of law and order to jump to conclusions about the dangers for women posed by the use of specific drugs by uncontrolled men. For example, Chavannes reports that how in Jamaica, from the early twentieth century cannabis (ganja) has been viewed and how it came to be associated with violence:

'Another negative reaction that ganja was, at one time, thought to provoke was a proneness to violence. This seemed to have been the reason for Jamaica including ganja in its ratification of the 1912 Hague Opium Convention signed by Great Britain, not on the basis of expert or scientific evidence but on the basis of unsubstantiated allegations. Forty years previously the Governor had mentioned in a report to the Colonial Office that it was believed that ganja had induced an Indian to murder his wife. Forty years later, allegation had become fact.' (Chavannes, 2004a, p. 179)

The Jamaican police, like their Ugandan counterparts, 40 years later, attempted to link specific drug use with rape. Hence, in Jamaica in the early 1960s, 'The police force also tried its own version of the United states Bureau of Narcotics campaign in trying, but without much success, to link ganja smoking to with the rise of crime, including rape.' (Chavannes, 2004b: 69)

A similar association between cannabis and violence was made in California during the 1930s. According to Feiling:

Across the USA at different times various substances have been associated with violence and rape (Feiling, 2009). US government officials in the twentieth century focused particularly on, cocaine and cannabis, and their scaremongering had a strongly racist dimension (Feiling, 2009). For example, Feiling reports that in the 1910s, a cocaine panic struck the US Southern states:

"Dr Christopher Koch of the state Pharmacy Board of Pennsylvania testified before Congress that 'most of the attacks upon the white of the South are the direct result of a cocaine-crazed Negro brain'." (Feiling, 2009: 21)

Hence, there is nothing unique, or even unusual, in the linking of drugs with violence. In the Ugandan press Somalis are described as 'sex maniacs' and some officials in interviews singled out Somalis as 'sex fiends' fuelled by khat. Yet, the Ugandan claim that khat makes people violent and likely to commit rape runs counter to even the arguments of the many campaigners against khat, a substance usually linked to 'idling' and lethargy (Beckerleg, 2009a,b).

On the other hand there is evidence that women chewers are particularly vulnerable to sexual violence. A study carried out in Ethiopia shows that women who chewed khat were more likely to suffer from gendered violence, including rape, than female nonchewers (Arnold et al., 2008). The authors attribute the linkage between khat and being victims of violence to the widespread research finding that 'women who consume alcohol and use illicit drugs are frequently viewed by men as being sexually available' (Arnold et al., 2008: 798). As in Lamu and amongst Somalis, such Ethiopian female khat chewers are perceived as lacking respectability and therefore as sexual 'prey'.

\section{Discussion}

The East African discourse on khat and sex, as played out in Kenya and Uganda, is not a scientifically informed debate. Indeed the 'science' concerning the effects of khat on libido and fertility is fragmentary and contradictory. In the popular discourse Kenyan and Ugandan khat consumers, local leaders, religious scholars and policy makers all use khat to bolster their own personal or group ideological perspectives, or for commercial gain, such as newspaper sales. Neither consumers nor researchers agree, even amongst themselves, whether khat increases or decreases sexual potency 
(Hakim, 2002; Gebissa, 2008). Only reporters for the Ugandan sensationalist newspaper, Red Pepper (2008), are apparently certain that khat is good for men seeking to prolong their sexual performance.

The ongoing debate on khat, libido and performance can be linked to male claims, led by Somali men in Kenya and Uganda, that women khat chewers are promiscuous. If khat has aphrodisiac properties, then women are courting sexual ruin by chewing khat, according to such thinking. Such arguments also open the way for anti-khat campaigners, who seek to portray khat as a cause of transmission of sexually transmitted infections, notably HIV. By singling out khat in this way they continue debates on women's sexuality and their place in urban East African society.

In the correspondence generated by the Lamu anti-khat campaign, the argument moved rapidly from khat and its links to prostitution, to the spread of AIDS. As sex workers are known across Africa to have high rates of HIV (Akeroyd, 2004), there is a logic behind the claim that 'khat causes AIDS' (Beckerleg, 2008). Although, reliable key informants in Uganda and Kenya report that individual women do trade sex for khat, there is no evidence that khat consumption causes women to become sex workers (Beckerleg, 2008). On the contrary, it appears that a large majority of women users are not sex workers and that khat dependence does not cause women to enter the sex trade in the way that heroin and crack cocaine addiction sometimes do (Beckerleg and Lewando, 2005; Bourgois, 1995; Romero-Daza et al., 2003).

Nevertheless, in Kenya and Uganda, where khat consumption is for most people, a recent leisure pursuit, female consumption is often stigmatised. In Kenya, only amongst the Tigania and Igembe sub groups of the Meru does khat have ritual significance. Khat has been cultivated in the Nyambene Hills for hundreds of years by these clans, and was presented to elders during dispute settlements and marriage negotiations (Carrier, 2005).

Carrier (2003) points out that khat is popular amongst sex workers in Kenya. Yet data from the survey of 300 consumers I conducted in Uganda in 2004, showed that only 5 of 71 women consumers said they were sex workers (Beckerleg, 2008). A greater number of the respondents reported chewing at home, often with their husbands. Nevertheless, Ugandan men express similar views that link female khat consumption with prostitution and label all economically independent and single women as morally compromised. Within Africa, independent women living in urban areas, have since colonial times been associated with commercial sexual activity (Talle, 1998). From the twentieth century until the present day, male labour migration resulted in family separation and male resort to single women to meet their sexual needs (Lyons, 2004). Many of urban sexual relationships had, and continue to have, a commercial aspect.

Somalis are closely associated with khat consumption both in East Africa and the diaspora, yet have little cultural association with khat use. Somalis live all over East Africa, as long term migrants and as refugees since the war of the early 1990s. However, since the Somali war and the resulting dispersal of many Somalis across the world, khat has been thrust into the limelight. Khat is commonly decried as destructive of the Somali social fabric (Dirie and D'Haem, 2002; Randall, 1993). Yet, khat consumption is a relatively recent cultural development for most Somalis (Beckerleg and Sheekh, 2005; Gebissa, 2004; Goldsmith, 1997). Consumption by Somali groups lack the social and cultural dimensions that khat exhibits in Ethiopia and Yemen, and as a pastime has legitimacy only amongst men. Amongst Somalis, male attitudes towards the female consumption of khat are judgmental and condemnatory. There is no cultural space to accommodate mixed chewing sessions, or even women chewing in seclusion. Any Somali women who chew khat openly are labelled 'prostitutes' and female khat traders are even more exposed to male opprobrium. As the female traders of north-east Kenya, attest, most small scale khat retailers must struggle alone to make ends meet because their husbands have failed to meet the responsibility of providing for the family (Beckerleg, 2008). Many Somali women benefit little from the khat trade and would prefer to trade in other goods, but are locked in because the credit system whereby they can pay wholesalers for good sold the following day, and always need to use the daily takings to buy the next day's supply. They make just enough to continue in trade and are unable to set aside capital to set up trade in another product (Anderson et al., 2007).

Women's khat use is not frowned upon in all parts of the world. In Ethiopia and Yemen, both countries with a long tradition of khat use, women regularly chew for recreation and as part of their social lives. In Ethiopia, far from being a stigmatised activity, khat is linked to Islamic observance in areas such as the Harege region where production and consumption date back centuries (Gebissa, 2004). Hence, in rural Ethiopia, Almeddom and Abraham attended women's khat chewing ceremonies where participants were encouraged to think good thoughts, while sitting in silence or quietly reciting the Quran, and conclude that: 'Tchat-chewing is part and constitutive of ritual purity and an affirmation of their social selves as good Muslim women' (1994: 256).

In Yemen, khat chewing is scheduled for certain times of day within a prescribed setting, and with men and women consuming at separate gatherings (Kennedy, 1987; Meneley, 1996). While male consumption rates are higher than found amongst women surveyed, (Varisco, 1986) female consumption is common particularly in Yemeni urban areas (Varisco, 1986, p. 5). Hence, khat use is integrated into social life, and even non-users of khat are happy to be associated with chewers without fear of being tainted by association. Hence, in Yemen, as in parts of Ethiopia, both countries with a long history of khat consumption, women have for for centuries been able to chew khat in gender segregated groups without fear of being labelled prostitutes (Beckerleg, 2008).

\section{Conclusions}

As with most aspects of this plant substance (Anderson et al., 2007), the evidence for each of the discourses on khat and sex is fragmentary and contested. Through the East African discourse on khat use men and women highlight aspects of changing views on sexuality. Male libido, female desire and fertility are discussed in khat chewing sessions. These discussions reflect the social change, in particular women's roles as independent traders, wives and girlfriends, occurring in East African urban centres. That the discourse is contradictory, with some people claiming khat is good for sexual performance and others claiming the opposite, reflects the differing physical and psychological reactions to the use of khat. The lay discourse in relation to sexual function and performance reflects the complexity and doubts concerning khat and sexuality, and is therefore more nuanced than the scientific discourse which seeks to present clear findings based on very little evidence.

In East Africa the discourse on khat and sex has led to consumption being associated with uncontrolled sexual behaviour by many people. There is no evidence that khat use fuels promiscuity, commercial sex, sexually transmitted diseases or rape. Rather, the lay discourse on khat and female consumption reflects the male hegemony of the region, with men seeking to control female sexuality (Akeroyd, 2004; Beckerleg, 2008).

The current discourse on khat touches on all these aspects of sexual behaviour, with the main focus on female morality. Local religious and political leaders invoke khat use as an example of 
societal breakdown. Social order, in turn depends, for the Swahili of Lamu, for Somali communities and for many other groups, on the control of female sexuality. For many men, women khat users are a threat to the moral order. In Kenya and Uganda it is women khat consumers who are seen as sexually uncontrolled. In Uganda, the argument is extended even to men: with male khat chewers labelled as prone to commit rape.

Yet, in East Africa increasing numbers of men and women of all ethnic backgrounds are adopting khat chewing a regular pastime. However, men have appropriated this new leisure pursuit, in the sense that only they, and not women, can enjoy khat without being socially stigmatised. In both Kenya and Uganda, it is male youth who are the most enthusiastic new consumers (Carrier, 2005; Beckerleg, 2006). Young women consumers must endure the stigma and slurs on their sexual morality by their male peers, and many may be deterred from taking up khat.

The East African discourse on khat and sex reveals much about sexual politics in the region, but little about the physical or psychological effects of khat use on sexual function and libido.

\section{Acknowledgements}

This findings presented here are part of an ESRC funded study, 'Khat and Social Identity in Uganda' (RES-062-23-0560) conducted between 2007 and 2009. Musa Almas is thanked for his assistance in carrying out fieldwork. All khat-consumers and other informants are thanked for their co-operation and for sharing their views on khat. Additional data were collected in 2004-2005, when I was one of the research team carrying out fieldwork in Kenya and Uganda, funded through an ESRC Award, 'The Khat Nexus: transnational consumption in a global economy' (RES-143-25-0046). The reviewers and Guest Editor are thanked for helpful comments in reviewing an earlier version of this paper.

\section{References}

Adeoya-Osiguwa, S.A., Fraser, L., 2004. Cathine and norephedrine, both phenylpropanolamines, accelerate capacitation and then inhibit spontaneous acrosome loss. Human Reproduction 20, 198-207.

Advisory Council on the Misuse of Drugs (ACMD), 2005. Assessment of risk to individual and community in the UK.

Akeroyd, A.V., 2004. Coercion, constraints, and "cultural entrapments": a further look at gendered and occupational factors pertinent to the transmission of HIV in Africa. In: Kalipeni, E., Craddock, S., Oppong, J.R., Ghosh, J. (Eds.), HIV and AIDS in Africa: Beyond Epidemiology. Blackwell Publishing, Oxford, pp. 89103.

Ainsworth, C., 2004. Khat drug may improve male fertility. New Scientist. http://www.newscientist.com/article/dn6086 (accessed 29.06.04).

Al-Mamary, M., Al-Habori, A.M., Al-Aghbari, Baker, M., 2002. Investigation into the toxicological effects of Catha edulis leaves: a short term study in animals. Phytotherapy Research 16, 127-132.

Almeddom, A., Abraham, S., 1994. Women, moral virtue and Tchat-chewing. In: MacDonald, M. (Ed.), Gender, Drink and Drugs. Berg, Oxford, pp. 249-58.

Anderson, D., Beckerleg, S., Hailu, D., Klein, A., 2007. The Khat Controversy: Stimulating the Drugs Debate. Berg, Oxford.

Anderson, D., Carrier, N., 2006. 'Flowers of paradise' or 'polluting the nation'? Contested narratives of khat consumption. In: Brewer, J., Trentmann, F. (Eds.), Consuming Cultures, Global Perspectives: Historical trajectories, Transnational Exchanges. Berg, Oxford, pp. 145-166.

Arnold, D., Goshu, M., Williams, M.A., 2008. Prevalence and risk factors of genderbased violence among female college students in Awassa, Ethiopia. Violence and Victims 23, 787-800.

Beckerleg, S., 2010. Ethnic Identity and Development: Khat and Social Change in Africa. Palgrave Macmillan, New York.

Beckerleg, S., 2009a. From ocean to lakes: cultural transformations of Yemenis in Kenya and Uganda. African and Asian Studies, 288-308.

Beckerleg, S., 2009b. Khat chewing as a new Ugandan leisure activity. Journal of East African Studies 3, 42-54.

Beckerleg, S., 2008. Khat in East Africa: taking women into or out of sex work. Substance Use and Misuse 43, 1170-1185.

Beckerleg, S., 2006. What harm? Kenyan and Ugandan perspectives on khat. African Affairs 104, 219-241.

Beckerleg, S., Sheekh, N., 2005. A view from the refugee camps: new Somali khat use in Kenya. Drugs and Alcohol Today 5, 25-27.
Beckerleg, S., 2004. How 'cool' is heroin use at the Kenya Coast? Drugs: Education, Policy, Practice 11, 67-77.

Beckerleg, S., Lewando Hundt, G., 2005. Women heroin users: exploring the limitations of the structural violence approach. International Journal of Drug Policy $16,183-190$.

Borelli, S., Perali, F., 2004. Drug consumption and intra-household distribution of resources. In: Dagum, C., Ferrari, G. (Eds.), Household Behaviour, Equivalence Scales, Welfare and Poverty. Physica-Verlag, Heidelberg.

Bourgois, P., 1995. In search of respect: Selling crack in El Barrio. Cambridge University Press, Cambridge.

Carrier, N., 2008. Is miraa a drug?: Categorizing Kenyan Khat. Substance Use and Misuse 43, 803-816.

Carrier, N., 2005. 'Miraa is cool': the cultural importance of miraa (khat) for Tigania and Igembe youth in Kenya. Journal of African Cultural Studies 17, 201218.

Carrier, N., 2003. The Social Life of Miraa: farming, trade and consumption of a plant stimulant in Kenya. Unpublished PhD thesis, University of St Andrews.

Chavannes, B., 2004a. Criminalizing cultural practice: the case of Jamaica. In: Klein, A., Day, M., Harriott, A. (Eds.), Caribbean Drugs: from Criminalization to Harm Reduction. Zed Books, London.

Chavannes, B., 2004b. 'Ganja and the road to decriminalization in Jamaica. In: Coomber, R.N. (Ed.), South Drugs in the Global Context: Comparative Perspectives on Cultures and Controls. Free Association Press, London.

Dhadphale, M., Omolo, O.E., 1988. Psychiatric morbidity amongst khat chewers. East African Medical Journal 65, 355-359.

Dirie, W., D’Haem, J., 2002. Desert Dawn. Virago, London.

Feiling, T., 2009. The Candy Machine: How Cocaine Took Over the world. Penguin, London and New York.

Gebissa, E., 2004. Leaf of Allah. Khat and Agricultural Transformation in Harerge, Ethiopia 1875-1991. James Currey, Oxford.

Gebissa, E., 2008. Scourge of life or an economic lifeline? Public discourses on Khat (catha edulis) in Ethiopia. Substance Use and Misuse 43, 784-802.

Goldsmith, P., 1997. The Somali impact on Kenya, 1990-1993: the view from the camps. In: Adam, H.M., Ford, R. (Eds.), Mending Rips in the Sky: Options for Somali Communities in the 21st Century. Red Sea Press, Lawrenceville and Asmara, pp. 461-483.

Hakim, L.Y., 2002. Influence of khat on seminal fluid among presumed infertile couples. East African Medical Journal 79, 22-28.

Ihunwo, A.O., Kayanja, F.I.B., Amadi-Ihunwo, U.B., 2004. Use and perception of the psychostimulant, khat (Catha edulis) among three occupational groups in south western Uganda. East African Medical Journal 81, 468-473.

Kennedy, J.G., 1987. The Flower of Paradise: The institutionalized use of the drug qat in North Yemen. D. Reidel Publishing Company, Dordrecht.

Klein, A., Beckerleg, S., 2007. Building castles of spit-the role of khat in ritual, leisure and work. In: Goodman, J., Lovejoy, P., Sherrat, A. (Eds.), Consuming Habits; global and Historical Perspectives on How Cultures Define Drugs. (New Edition). Routledge, Abingdon, pp. 238-254.

Klein, A., Beckerleg, S., Hailu, D., 2009. Regulating khat-dilemmas and opportunities for the international drug control system. International Journal of Drug Policy 20 (6), 509-513.

Lyons, M., 2004. Mobile populations and HIV/AIDS in East Africa. In: Kalipeni, E., Craddock, S., Oppong, J.R., Ghosh, J. (Eds.), HIV and AIDS in Africa: Beyond Epidemiology. Blackwell Publishing, Oxford.

Meneley, A., 1996. Tournaments of Value: Sociability and Hierarchy in a Yemeni Town. University of Toronto Press, London.

Mwenda, J.M., Arimi, M.C., Kyama, M.C., Langat, D.K., 2003. Effects of khat (Catha edulis) chewing on reproductive functions. East African Medical Journal 80, 318-323.

Mwenda, J.M., Owuor, R.A., Kyama, M., Wango, Arimi, M.C., Langat, D.K., 2006. Khat (Catha edulis) up-regulates testosterone and decreases prolactin and cortisol levels in the baboon. Journal of Ethnopharmacology 103, 379-384.

Nyongesa, A.W., Patel, N.B., Onyango, D.W., Wango, E.O., Odongo, H.O., 2007. In vitro study of the effects of khat (Catha edulis Forsk) extract on isolated mouse interstitial cells. Journal of Ethnopharmacology 110, 401-405.

Odenwald, M., 2007. Chronic khat use and psychotic disorders: a review of the literature and future prospects. SUCHT 53, 9-22.

Randall, T., 1993. Khat abuse fuels Somali conflict, drains economy. JAMA-Journal of the American Medical Association 269, 12-14.

Red Pepper, 2008. Sex and Mairungi. Fame Magazine Supplement. Red Pepper 13 July, 7-9.

Republic of Kenya, 2009. Kenya Aids Indicator Survey. Republic of Kenya September.

Romero-Daza, N., Weeks, N., Singer, M., 2003. Nobody gives a damn if I live or die: violence, drugs and prostitution in inner-city Hartford, Connecticut. Medical Anthropology 22, 233-259.

Ryan, C., 2004. Khat plant boosts sperm power. BBC News. http://news.bbc.co.uk/ $1 /$ health/3845635.stm (accessed 28.06.04).

Talle, A., 1998. Modernity among female bar workers in Tanzania. In: Abram, S., Waldren, J. (Eds.), Anthropological Perspectives on Local development: Knowledge and Sentiments in Conflict. Routledge, London.

Varisco, D.M., 1986. On the Meaning of Chewing - the Significance of Qat (Cathaedulis) in the Yemen-Arab-Republic. International Journal of Middle East Studies $18,1-13$

Warfa, N., Klein, A., Bhui, K., Leavey, G., Craig, T., Stansfeld, S., 2007. Association between khat use and mental disorders: an emerging paradigm. Social Science and Medicine 65, 309-318. 